\title{
Natural Course of Branch Retinal Vein Occlusion up to 3 Months for Early Referral Cases ${ }^{\S}$
}

\author{
Erken Başvuran Retina Ven Dal Tıkanıklığı Olgularının Ilk 3 Aylık Doğal Seyri
}

\author{
Emir Volkan Altan $\odot$, Ismail Umut Onur ${ }^{\oplus}$, Ozge Pinar Akarsu Acar $\odot$, Fadime Ulviye Yigit $\odot$ \\ Department of Ophthalmology, Bakirkoy Dr. Sadi Konuk Training and Research Hospital, Istanbul, Turkey
}

Received: 6 July 2019 / Accepted: 27 December 2019 / Publication date: 26 June 2020

Cite as: Altan EV, Onur IU, Akarsu Acar OP, Yigit FU. Natural course of branch retinal vein occlusion up to 3 months for early referral cases. Med J Bakirkoy 2020;16(2):114-9.

\begin{abstract}
Objective: To evaluate functional and anatomical changes in branch retinal vein occlusion (BRVO) up to 3 months in early referral BCVA cases.

Method: Twenty-three eyes of 23 consecutive BRVO patients diagnosed within 4 weeks of symptom onset were enrolled in this prospective, observational study. Eyes were followed up without treatment. Measurements in best corrected visual acuity (BCVA) and central macular thickness (CMT) at the baseline, 2 weeks, 1 month and 3 months were evaluated.

Results: The improvement in mean BCVA from the baseline to 2 weeks $(p=0.043), 1$ month $(p=0.012)$ and 3 months was found statistically significant ( $p=0.001)$. Despite a decrease in central macular thickness (CMT) was observed, the change in CMT from the baseline to 3 months did not reach a clinical significance $(p=0.068)$.

Conclusion: Considering the natural course in BRVO, follow-up without treatment may also be acceptable up to the first 3 months. Our results indicate that delaying treatment up to 3 months is not associated with increased CMT or deteriorated BCVA for recent onset early referral BRVO cases.
\end{abstract}

Keywords: natural course, branch retinal vein occlusion, best corrected visual acuity, central macular thickness

Öz

Amaç: Erken başvuran retina ven dal tıkanıklığı (RVDT) olgularında ilk 3 aydaki işlevsel ve anatomik değişiklikleri incelemek. Yöntem: Semptomların ortaya çıkışıyla ilk 4 hafta içerisinde RVDT tanısı alan ardışık 23 hastanın 23 gözü prospektif, gözlemsel çalışmaya dahil edildi. Gözler sadece tedavisiz takip edildi. Başlangıçta alınan en iyi düzeltilmiş görme keskinliği (EiDGK) ve santral makula kalınlığı (SMK) ölçümleri 2. haftada, 1. ayda ve 3. ayda tekrarlandı. Bu parametrelerdeki değişimler analiz edildi.

Bulgular: Ortalama EiDGK'de başlangıca göre 2. haftada, 1. ayda, 3. ayda istatistiksel olarak anlamlı düzelme kaydedildi (sırasıyla $p=0,043, p=0,012, p=0,001)$. Ortalama SMK'da ise başlangıca göre 3. ayda azalma izlenmiş olsa da fark istatistiksel olarak anlamlı bulunmadı $(p=0.068)$.

Sonuç: RVDT’nin doğal seyri ile birlikte düşünüldüğünde ilk 3 aya kadar tedavisiz gözlem, bir seçenek olarak değerlendirilebilir. Çalışmamızın sonuçları, erken başvuran olgularda tedavinin 3 aya kadar bekletilmesinin EiDGK ve SMK parametreleri üzerinde olumsuz bir etki ilişkili olduğunu göstermemiştir.

Anahtar kelimeler: doğal seyir, retina ven dal tıkanıklığı, en iyi düzeltilmiş görme keskinliği, santral makula kalınlığı

Corresponding Author:

umuton@gmail.com
E. V. Altan 0000-0001-9293-9143

i. U. Onur 0000-0002-9028-2421

O. P. Akarsu Acar 0000-0003-4424-2215

F. U. Yigit 0000-0003-0176-1509

${ }^{\S}$ Derived from the thesis of E. Volkan Altan 2014- Istanbul

(C) Telif hakkı Sağlık Bilimleri Üniversitesi Bakırköy Dr. Sadi Konuk Eğitim ve Araştırma Hastanesi'ne aittir. Logos Tıp Yayıncılık tarafindan yayınlanmaktadır. Bu dergide yayınlanan bütün makaleler Creative Commons Atff-GayriTicari 4.0 Uluslararası Lisansı ile lisanslanmıştr.

(c) Copyright Health Sciences University Bakırköy Sadi Konuk Training and Research Hospital. This journal published by Logos Medical Publishing.

Licenced by Creative Commons Attribution-NonCommercial 4.0 International (CC BY-NC 4.0) 


\section{INTRODUCTION}

Retinal vein occlusion (RVO) is the second most common retinal vascular disorder after diabetic retinopathy, and causes visual loss commonly associated with macular edema and retinal ischemia ${ }^{(1,2)}$. Current options for the treatment of RVO complications include applications of argon laser photocoagulation, intravitreal corticosteroids and anti-vascular endotelial growth factors (anti-VEGFs) ${ }^{(3,4)}$. However, several attempts have been made to perform anastomoses using surgery and laser or relieve the obstruction pharmacologically by thrombolytics and bypass the congestion via optic nerve sheathotomy, which all proved ineffective ${ }^{(5)}$.

A number of multicenter trials have evaluated the efficacy of argon laser photocoagulation, intravitreal corticosteroids and anti-VEGFs in RVO. Nevertheless, a common aspect of all these studies was the relatively long duration between symptom onset and treatment, which generally exceeded 3 months ${ }^{(6-11)}$. In systematic reviews and meta-analyses on the natural course of ocular complications in patients with untreated symptomatic branch retinal vein occlusion (BRVO), it has been reported that the best corrected visual acuity (BCVA) generally improves up to 2 lines or by 1 letter at 3 months and up to 15 letters over 18 months in one third to three quarters of eyes ${ }^{(5-8)}$. Current data on the timing of treatment for recent onset BRVO is not clear and evidence is not strong on this issue. The aim of this study was to observe the functional and anatomical changes in early referral BRVO patients without any treatment up to 3 months.

\section{MATERIALS and METHODS}

The study was conducted in accordance with the tenets of the Declaration of Helsinki. Informed consent was obtained from all individual participants included in the study with the approval of the institutional ethical review board (Approval number: 2014/61).

Twenty-three eyes of consecutive 23 BRVO patients diagnosed within 4 weeks of symptom onset between September 2011 and March 2014 were enrolled in this prospective, observational study conducted at our tertiary eye department. At first visit, a question- naire on medical history, family background and drug use was applied to all patients requiring specifically for personal or family history of hypertension, diabetes mellitus, thrombophilia, spontaneous abortion, pulmonary embolism or deep venous thrombosis and use of oral contraceptive drugs. Hematology and cardiology consultations were requested for the evaluation of cardiovascular and hematologic risk factors including hypertension, hyperlipidemia, hyperhomocysteinemia, presence of factor $\mathrm{V}$ Leiden mutation and thrombophilic disorders. Detailed ophthalmic examinations were carried out. BCVA was expressed as decimal units and was converted to the logarithm of the minimal angle of resolution (log MAR) for statistical analyses. Intraocular pressure (IOP) measurement with noncontact tonometer (Topcon CT-80, Tokyo, Japan), and assessments using slit-lamp biomicroscopy, dilated fundus examination, optical coherence tomography (OCT) and colored fundus photography imaging were performed. These examinations were repeated at 2 weeks, 1 month and 3 months. Patients with a history of intraocular surgery, diagnosed or suspected glaucoma or mature cataracts preventing OCT examination were excluded from the study. A technician performed the OCT examinations with RTVue-100 OCT device (Optovue Inc., Fremont, US), which had a $5 \mu \mathrm{m}$ axial image resolution with a speed of 27.000 scans per second for all macular measurements. All eyes were assessed 30 minutes after topical tropicamide $1 \%$ administration for signal strength enhancement. Segmental division in MM5 protocol outputs ( $5 \times 5 \mathrm{~mm}^{2}$ grid of 11 horizontal and 11 vertical lines with $668 \mathrm{~A}$-scans each and $3 \times 3 \mathrm{~mm}^{2}$ inner grid of 6 horizontal and 6 vertical lines with 400 A scans each) with retinal thickness of $1 \mathrm{~mm}$ diameter central ring (CMT-central macular thickness retinal thickness) on thickness map was recorded.

Fundus photography and fundus fluorescein angiography (FFA) were performed by an experienced physician using Kowa VX-10i retinal camera (Kowa Optimed Europe Ltd., Berkshire, UK). Fundus photographs were taken at the baseline, second week, first and third months and then reevaluated by two physicians. Reduction in the bleeding area and the number of punctate hemorrhages, disappearance of the exudates, recovery of venous tortuosity and distension were accepted as recovery criteria. Because 
fresh retinal hemorrhages generally preclude the examination of retinal capillaries and the macula in the acute phase, FFA examinations were not performed at presentation, but later within the first 3 months of BRVO. Location of BRVO, existence of ischemia and neovascularization were analysed with FFA. The retinal ischemia was defined as the presence of capillary non-perfused areas after the hemorrhages cleared up.

\section{Statistics}

In the descriptive summary of the data, mean, standard deviation (SD), median (med), first quarterthird quarter (Q1-Q3), frequency and ratio values were used whenever appropriate. The distribution of the variables was assessed by the KolmogorovSmirnov test. Mann-Whitney $U$ test and chi-square test were used in the analysis of qualitative and quantitative data, respectively. Wilcoxon test and Mc Nemar's test were used in the repetitive measurements. Analyses were performed with SPSS 22.0 (IBM Corporation, New York, US) software.

\section{RESULTS}

In this study 23 eyes of 23 patients, 16 (69.6\%) male and 7 (30.4\%) female with early referral BRVO were analysed. None of the patients declared hypertension and any cardiovascular or hematologic risk factors were not detected in the study group at presentation. The demographic characteristics of the patients included in the study are summarized in Table 1.
At the baseline visit, the mean BCVA (log MAR) was $0.57 \pm 0.40$ (Med $=0.52$ ). Only $6(26.09 \%$ ) eyes had a BCVA higher than 0.4 decimal units and 17 (73.91\%) eyes had a BCVA lower than 0.5 decimal units (Table 2). At 2 weeks of follow up, BCVA improved 1 line or more in $12(57.1 \%)$ of the eyes. BCVA did not change in $5(23.8 \%)$ of the eyes and a 1 line loss in BCVA was detected only in 4 (19.1\%) eyes. In comparison with baseline at 1 month, an improvement of 1 line or more in BCVA was seen in $13(65 \%)$ of the eyes. BCVA did not change in $4(20 \%)$ eyes and 1 line loss was detected in 3 (15\%) eyes. At 3 months, in 16 (69.6\%) eyes, BCVA improved 1 line or more. BCVA did not change in 6 (26.1\%) of the eyes and a 1 line loss was detected in 1 eye (4.3\%) (Table 2 and Figure 1). At 3 months, the mean BCVA (log MAR) was 0.34 \pm 0.39 (Med $=0.04$ ). Fourteen (61\%) eyes had a BCVA higher than 0.4 decimal units and 9 (39\%) eyes had a BCVA lower than 0.5 decimal units (Table 2). The change in BCVA from baseline to 2 weeks $(P=0.043), 1$ month $(P=0.012)$ and 3 months was found statistically significant $(P=0.001)$.

The mean central macular thickness (CMT) measured with OCT at the baseline, 2 weeks, 1 month and 3 months were $437 \mu \mathrm{m} \pm 158 \mu \mathrm{m}$ (Med=451 $\mu \mathrm{m})$, $423 \mu \mathrm{m} \pm 181 \mu \mathrm{m}$ (Med=385 $\mu \mathrm{m}$ ), $423 \mu \mathrm{m} \pm 193 \mu \mathrm{m}$ (Med $=359 \mu \mathrm{m})$ and $363 \mu \mathrm{m} \pm 116 \mu \mathrm{m}(\mathrm{Med}=315 \mu \mathrm{m})$, respectively. Although the change in $\mathrm{CMT}$ from the baseline to 3 months was not statistically significant $(p=0.068)$ an improvement in macular edema and a decrease in the central macular thickness were detected (Figure 2).

Table 1. Demographics.

\begin{tabular}{|c|c|c|c|c|c|}
\hline & Med & Q1-Q3 & Mean $\pm S D$ & $\mathbf{n}$ & $\%$ \\
\hline Age (years) & 52 & $43-60$ & $53.7 \pm 13.2$ & & \\
\hline \multicolumn{6}{|l|}{ Gender } \\
\hline Female & & & & 7 & $30.4 \%$ \\
\hline Male & & & & 16 & $69.6 \%$ \\
\hline Duration of symptoms at referral (day) & 15 & $4-25$ & $14.6 \pm 9.8$ & & \\
\hline \multicolumn{6}{|l|}{ Eye } \\
\hline Right & & & & 12 & $52.2 \%$ \\
\hline Left & & & & 11 & $47.8 \%$ \\
\hline Refraction (Diopters) (SE) & 0.12 & $-0.50-0.62$ & $0.20 \pm 2.10$ & & \\
\hline \multicolumn{6}{|l|}{ Location of BRVO } \\
\hline Inferior Temporal & & & & 5 & $21.7 \%$ \\
\hline Superior Temporal & & & & 18 & $78.3 \%$ \\
\hline
\end{tabular}


Table 2. BCVA (Log Mar).

\begin{tabular}{|c|c|c|c|c|}
\hline Case & Baseline & 2 weeks & 1 month & 3 Months \\
\hline 1 & 0.39 & 0.04 & 0.04 & 0 \\
\hline 2 & 0.69 & 0.22 & 0.04 & 0.04 \\
\hline 3 & 0 & 0 & 0 & 0 \\
\hline 4 & 1 & 1.3 & 0.82 & 0.69 \\
\hline 5 & 1.52 & 1.52 & 1.3 & 0.69 \\
\hline 6 & 0.69 & 1 & 1 & 0.69 \\
\hline 7 & 0.39 & 0.3 & 0.22 & 0.22 \\
\hline 8 & 0.69 & 0,3 & 0.22 & 0.3 \\
\hline 9 & 0.09 & 0.15 & 0.15 & 0.04 \\
\hline 10 & 1 & 0,52 & 0.15 & 0.04 \\
\hline 11 & 1 & 1 & 1 & 1 \\
\hline 12 & 0.39 & 0.3 & NA & 0.04 \\
\hline 13 & 1 & 1 & 1 & 1.3 \\
\hline 14 & 0.3 & 0,22 & 0.09 & 0.04 \\
\hline 15 & 0.04 & 0.15 & 0.22 & 0.04 \\
\hline 16 & 0.52 & 0.52 & 0.52 & 0.52 \\
\hline 17 & 0,82 & 0.52 & 0.69 & 0.69 \\
\hline 18 & 0.15 & 0.09 & 0.04 & 0 \\
\hline 19 & 0.09 & 0 & 0 & 0 \\
\hline 20 & 0.15 & 0 & 0.04 & 0.04 \\
\hline 21 & 0.69 & NA & NA & 0.69 \\
\hline 22 & 0.39 & NA & NA & 0.04 \\
\hline 23 & 1 & 0.52 & 0.52 & 0.69 \\
\hline
\end{tabular}

Data of 23 patients with recent onset BRVO showing relationship to the location of the occlusion and best corrected visual acuity (BCVA).

The change in hemorrhage size, number of punctate hemorrhages, exudates, venous tortuosity and distension in fundus photographs were evaluated and a significant improvement was found at 1 month and 3 months compared to the baseline. FFA examinations revealed no macular ischemia or neovascularization in the study group. Peripheral capillary non-perfusion was detected in $13 \%$ of the patients. However, none of the patients developed retinal neovascularization, abnormal rise in IOP, involvement of the other eye or systemic cardiovascular pathologies such as myocardial infarction or cerebrovascular occlusion within the 3 months of follow-up period.

\section{DISCUSSION}

Our results indicate that in eyes with recent onset early referral BRVO, delaying treatment up to 3 months may not be associated with increased CMT or deteriorated BCVA. Indeed, we have observed a slow and limited recovery in the affected eyes in the 3 -month follow up period.

A number of pivotal multicenter randomized trials have investigated the management and treatment of

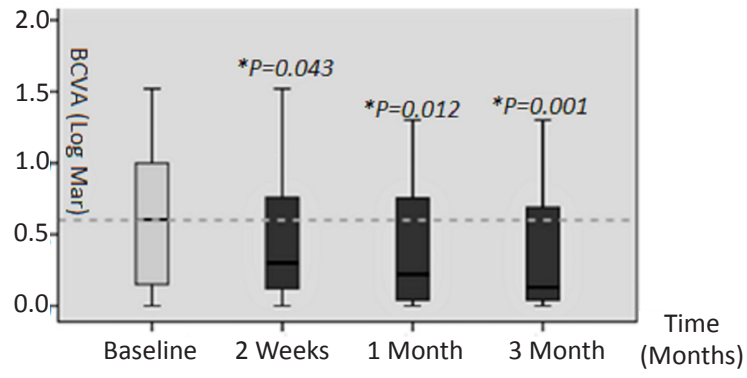

Figure 1. Change in mean BCVA (Log MAR).

*The changes in BCVA from baseline to 2 weeks ( $p=0.043), 1$ month $(p=0.012)$ and 3 months $(p=0.001)$ were found to be statistically significant.

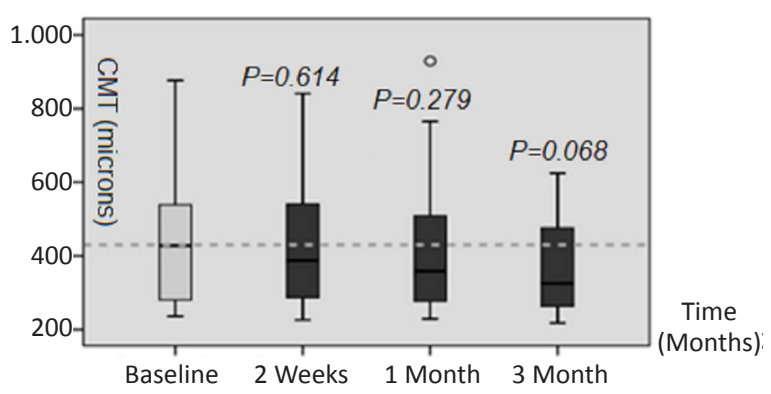

Figure 2. Change in mean CMT (microns).

complications in BRVO. However, cases enrolled in these studies display a heterogeneous duration of symptoms from the onset of the disease dispersed over a wide range. The multicenter, randomized laser trial [Branch Vein Occlusion Study (BVOS)] included the BRVO patients with symptom duration between 3 to 19 months ${ }^{(7,8)}$, while The Standard Care versus Corticosteroid for Retinal Vein Occlusion (SCORE) trial included the patients with a mean symptom duration of 4 months (range,1-24 months) (9). However, anti VEGF-ranibizumab (BRAVO) trial enrolled patients with a relatively uniform symptom duration, ranging between 3.3 months to 3.7 months (10). In the dexamethasone intravitreal implant (GENEVA) trial, the average time interval between symptom onset and treatment was 153 (49-944) days ${ }^{(11)}$. Compared to these multicenter, randomized studies mentioned above, the average duration of symptoms for the patients in our study was significantly shorter with 14.6 days (range: $1-30$ days).

Regarding natural course, Shroff et al. studied 20 patients with recent onset BRVO with duration of symptoms less than 6 weeks and reported an average improvement of $19.6 \%$ from the baseline in 
BCVA at 6 months ${ }^{(12)}$. BRAVO study reported that the patients in the sham group gained an average of 7.3 (5.1-9.5) letters at 6 months ${ }^{(10)}$. The multicenter, randomized, sham-controlled GENEVA study reported that BCVA improved 3 lines or more in the $18 \%$ of the patients in the sham group and $22 \%$ of the patients in the $0.7 \mathrm{mg}$ dexamethasone implant group at month 6 and the difference between the groups remained statistically insignificant ${ }^{(11)}$. Kwon et al. studied BRVO patients in 3 groups which received intravitreal triamcinolone injections, intravitreal bevacizumab injections or intravitreal sham treatment. At 6 months, statistically significant BCVA improvement from the baseline was only detected in the sham treatment group which reached 0.3 or more log MAR units of improvement in $55.2 \%$ of the patients at month $12^{(13)}$. Of note, improvement from the baseline in mean BCVA was significant in our study at all visits.

On the other hand, a functional and an anatomical threshold for starting up treatment have been adopted in all randomized trials. BCVA, less than 0.5 decimal units with detection of macular edema by OCT was accepted as treatment criteria in the previous studies (7,9-11). In the laser era, BVOS recommended performing grid laser photocoagulation after 3 months of presentation when BCVA is lower than 0.5 decimal units and persistent macular edema is present, since BCVA and macular edema may improve spontaneously in the first 3 months after onset of symptoms ${ }^{(7,8)}$.

The OCT examinations are important to detect macular edema; but increase in CMT currently is not accepted as an indication for treatment independent of BCVA. Relevantly, the GENEVA study reported that the change in CMT between the sham, $0.35 \mathrm{mg}$ dexamethasone implant and $0.7 \mathrm{mg}$ dexamethasone treatment groups to be statistically insignificant at 6 months ${ }^{(11)}$. Similarly, Kwon et al. reported that the changes in mean CMT between sham, intravitreal triamcinolone injection and intravitreal bevacizumab injection groups to be statistically insignificant at 12 months ${ }^{(13)}$. Furthermore, Shroff et al studied the natural course of CMT in early onset $(<6$ weeks) BRVO patients and found the mean baseline CMT of $398.9 \mu \mathrm{m}$ reducing to $346.8 \mu \mathrm{m}$ at 3 months. This change was statistically insignificant, but a gradual decline was highlighted in CMT up to month $7^{(12)}$.The change in CMT from baseline values was similarly statistically insignificant at 2 weeks, 1 month and 3 months in our study and we also observed a gradual decline in CMT like Shroff et al.

It has been proposed in the consensus document of RVO Guidelines Development Group, that the prognosis is favorable and follow-up without any treatment may be reasonable in BRVO patients with a perfused periphery and preserved BCVA above a predetermined threshold as long as monthly followups for the first three months are possible ${ }^{(3,6)}$. FFA should be performed to detect the location of retinal vein occlusion and nonperfused areas. The size of peripheral or macular nonperfusion and the existence of neovascularization should be evaluated as well, because the natural course of BRVO is associated with the location of occlusion, arterial perfusion at the BRVO area, and the efficiency of collateral circulation on nonperfused retina ${ }^{(14,15)}$. Monthly monitorization for the first three months is advised in case of a decrease in BCVA and development of macular edema ${ }^{(3)}$. On the contrary, a recent prospective, multicenter clinical trial has reported that the improvement in BCVA over 6 months in BRVO or CRVO patients with recent onset macular edema was found to be better in the early ( $<90$ days) dexamethasone intravitreal implant treatment group. However, this study included patients who had been previously treated for RVO ${ }^{(16)}$, whereas in our study all eyes were treatment- naive. In addition, Pacella et al. compared the effects of early (within 7 days of diagnosis) and delayed ( $>7$ day after diagnosis) dexamethasone implant treatment on 35 BRVO and 46 CRVO patients without a history of a previous laser treatment or intravitreal injection and found no significant differences in therapeutic response (17). According to an another recent, prospective, multicenter clinical trial (BRIGHTER study) patients with a shorter BRVO duration until treatment has a better BCVA gain than those with a longer BRVO duration. However, the mean time between symptom onset and treatment was 9.9 months and the median time between symptom onset and treatment was 2.9 months in this study ${ }^{(18)}$.

\section{STUDY LIMITATIONS}

The major limitations of this study are the limited number of patients and 3 months of follow-up time. 
However, early referral of treatment naïve eyes with BRVO to a tertiary ophthalmology department is not common. We also ended follow-up without treatment at month 3 according to the results that multicentered, randomized studies indicated in favor of treatment thereafter.

\section{CONCLUSION}

In conclusion, there is a trend for very early intervention for the patients with BRVO regardless of natural course, even in cases with preserved BCVA. However, follow-up without intervention for a while may also be acceptable given the natural course of BRVO. Subgroup analysis of outcomes stratified according to the duration and onset of symptoms in the pivotal randomized studies will aid in identifying the optimal approach based on patient characteristics.

\section{ACKNOWLEDGEMENTS}

Authors thank to Murat Icen, MD for English proofreading.

Ethics Committee Approval: Bakırköy Dr. Approval was obtained from Sadi Konuk Training and Research Hospital Clinical Research Ethics Committee (2014/61, 14.03.2014).

Conflict of interests: None of the authors have disclosed financial interest related to this study.

Funding: No grants or funding have been received for this study.

Informed Consent: Informed consent was obtained from all individual participants included in the study with the approval of the institutional ethical review board (Approval number: 2014/61).

\section{REFERENCES}

1. Frangieh GT, Green WR, Barraquer-Somers E, et al. Histopathologic study of nine branch retinal vein occlusions. Arch Ophthalmol. 1982;100(7):1132-40.

https://doi.org/10.1001/archopht.1982.01030040110020

2. Bandello F, Querques G. Medical Retina. 2012 ESASO Course Series. Basel, Karger. Vol 1. p. 111-8. https://doi.org/10.1159/isbn.978-3-8055-9991-7

3. Coscas G, Loewenstein A, Augustin A, et al. Management of Retinal Vein Occlusion - Consensus Document. Ophthalmologica. 2011;226(1):4-28. https://doi.org/10.1159/000327391

4. Laouri M, Chen E, Looman M, et al. The burden of disease of retinal vein occlusion: review of the literature. Eye.
2011;25:981-8. doi: 10.1038/eye.2011.92.

https://doi.org/10.1038/eye.2011.92

5. Ip M, Hendrick A. Retinal Vein Occlusion Review. Asia-Pac J Ophthalmol. 2018;7:40-5. https://doi.org/10.22608/APO.2017442

6. Rogers SL, McIntosh RL, Lim L, et al. Natural history of branch retinal vein occlusion: an evidence-based systematic review. Ophthalmology. 2010;117(6):1094-1101.e5. https://doi.org/10.1016/j.ophtha.2010.01.058

7. Branch Vein Occlusion Study Group. Argon laser photocoagulation for macular edema in branch vein occlusion. Am J Ophthalmol. 1984;98(3):271-82. https://doi.org/10.1016/0002-9394(84)90316-7

8. BVOS Group. Argon laser scatter photocoagulation for prevention of neovascularization and vitreous hemorrhage in branch vein occlusion. A randomized clinical trial. Branch Vein Occlusion Study Group. Arch Ophthalmol. 1986;104(1):3441. https://doi.org/10.1001/archopht.1986.01050130044017

9. Scott IU, VanVeldhuisen PC, Oden NL, et al. The Standard Care vs Corticosteroid for Retinal Vein Occlusion (SCORE) Study Study Report 1: Baseline Associations between Central Retinal Thickness and Visual Acuity in Patients with Retinal Vein Occlusion. Ophthalmology. 2009;116(3):504-12. https://doi.org/10.1016/j.ophtha.2008.10.017

10. Campochiaro PA, JeffreyS, Heier JS, et al. BRAVO Investigators. Ranibizumab for macular edema following branch retinal vein occlusion: six month primary end point results of a phase III study. Ophthalmology. 2010;117(6):1102-1112.e1. https://doi.org/10.1016/j.ophtha.2010.02.021

11. Haller J, Bandello F, Belfort R Jr, et al. OZURDEX GENEVA Study Group. Randomized, sham-controlled trial of dexamethasone intravitreal implant in patients with macular edema due to retinal vein occlusion. Ophthalmology. 2010;117(6):11341146.e3. https://doi.org/10.1016/j.ophtha.2010.03.032

12. Shroff D, Mehta DK, Arora R, et al. Natural history of macular status in recent-onset branch retinal vein occlusion: an optical coherence tomography study. Int Ophthalmol. 2008;28(4): 261-8. https://doi.org/10.1007/s10792-007-9123-0

13. Kwon SI, Kim YW, Bang YW, et al. Comparison of natural course, intravitreal triamcinolene, and intravitreal bevacizumab for treatment of macular edema secondary to branch retinal vein occlusion. J Ocul Pharmacol Ther. 2013;29(1):5-9. https://doi.org/10.1089/jop.2011.0249

14. Michels RG, Gass JDM. Natural course of temporal retinal branch occlusion. Trans Am Acad Ophthalmol Otolaryngol. 1974;78:166-77.

15. RehakJ, Rehak M. Branch Retinal Vein Occlusion: Pathogenesis, Visual Prognosis, and Treatment Modalities. Curr Eye Res. 2008;33(2):111-31. https://doi.org/10.1080/02713680701851902

16. Eter N, Mohr A, Wachtlin J, et al. Dexamethasone intravitreal implant in retinal vein occlusion: real-life data from a prospective, multicenter clinical trial. Graefes Arch Clin Exp Ophthalmol. 2017;255(1):77-87. https://doi.org/10.1007/s00417-016-3431-x

17. Pacella F, La Torre G, Basili S, et al. Comparison between early or late intravitreal injection of dexamethasone implant in branch (BRVO) or central (CRVO) retinal vein occlusion: sixmonths follow-up. Cutan Ocul Toxicol. 2017;36(3):224-30. https://doi.org/10.1080/15569527.2016.1254648q

18. Tadayoni R, Waldstein SM, Boscia F, et al. Individualized stabilization criteria-driven ranibizumab versus laser in branch retinal vein occlusion: six months results of BRIGHTER. Ophthalmology. 2016;123(6):1332-44. https://doi.org/10.1016/j.ophtha.2016.02.030 